\title{
THE EFFECT OF ENGLISH SUBTITLE IN “ZOOTOPIA” MOVIE IN SPEAKING SKILL
}

\author{
Fhuri Megawati ${ }^{1)}$, Ermawati Z. Nuroh ${ }^{2)}$ \\ English Education Study Program Faculty of Teacher Training and Education \\ Universitas Muhammadiyah Sidoarjo \\ Fhurimega11@gmail.com ${ }^{1)}$,ermawati@umsida.ac.id ${ }^{2)}$
}

\begin{abstract}
This study investigated the effect of using English Subtitle in "Zootopia" Movie as media in speaking skill of SMPN 6 Sidoarjo. English Subtitle can describe as practice media to help the students when they understand to watch movie. The method used Quasi Experimental Design. The result of this study showed that the student could improve their ability in speaking skill through English subtitle. The data got from both pre-test and post-test score were analyzed using T-test formula. The result of calculation showed that in the significance degree of $5 \%$, the value of t-test (to) is higher than t-table (tt) $(19.90>1.99)$. According to the criteria of the test, the result showed that there is an effect of student's in speaking skill using English subtitle. It can be concluded that English Subtitle in "Zootopia" movie as media is effective and applicable approach at the ninth grade of SMPN 6 Sidoarjo to improve student in speaking skill.
\end{abstract}

Keywords: English Subtitle, Movie, Speaking Skill

\section{INTRODUCTION}

For the most part, English proficiency has four skills. There are listening, speaking, reading, and writing. Among the four skills, speaking is said to be effective communicate with people. According to Hughes (2002: 133) states, many educators consider speaking as the best method for picking up a rapidly learning and properly of speech as the establishment for good written work. The educators contended that amid all one's life one will be most likely talk more than one speaker. Consequently, to a language instructor, great educating of speaking is regularly an esteemed issue in the division of ESL/EFL. As Renandya, (1999: 230) said speaking is one of the central components of conveying with people. But some people think that speaking is very difficult. Then, the students think also. According to Santoso, Dian (2017: 22) said problems happened at the class of speaking that the students are not afraid to make grammatical mistakes, although they still have a lot of errors. Besides, they have collection of vocabulary and understand how to use it.

Speaking learning will be very interesting if teaches give it appropriately through media. Media is all forms and channels used to convey information or messages. Many kinds of media can be used to reduce student boredom. These media are divided into visual, audio and textual media. Every media has several special advantages. There are a lot of foreign movies, tv shows, tv series that are broadcasted throughout the world. The popularity of social media and other platforms also allow us to watch subtitled videos in different languages. This phenomenon made the language experts and educators utilize these audio-visual products as one of their teaching media in their classes. Researches show that these 
kind of audio-visual media has been claimed as one of effective tools in foreign language classes. The media is movie. Why does the researcher use movie? Because movie can learning tool and entertaining facilities to improve the speaking skill of children more effective. According to the theory of Borrás, (1994: 61) said something else "Adversary of the utilization of subtitled video in foreign/second language instructing content that nearness of subtitles is diverting and they slower to create of understudies listening capacities. Defenders of subtitles, on the other way, that subtitles can help create speaking capability by empowering students to be aware of speaking that they do not generally get it". According to Megawati Fika said that students can build English communication if they can speak the target language with the teacher, friends, or others confidently and fluently. To produce effective speaking ability, communication strategy plays an important role in order to avoid misunderstanding or problems that may appear in the conversation.

The important thing to use media is to know the way to use it because it is used in the classroom to avoid student boredom. One way is changing the learning method by using Projected Motion Media. The project motion media is teaching learning from show image, by movie in the laptop or computer, for example, television, video (VCD, DVD, VTR), and computer. Using movie media in education and teaching in the classroom is very useful mainly to develop thoughts and opinions the students, including memory to the lesson, developing the power of fantasy the students, growing to be interest and motivation to learn. For example, Zootopia, Stand and Deliver, Forrest
Gump, Dangerous Minds, and Lean on Me. In this case, there are movie cannot be separated from the subtitle, especially western movie. The using of English subtitles as a medium of language learning has been much in the research. Students can get many new vocabularies and improve speaking skills from English subtitle because it subtitle in the western movie indicates which words are being spoken by the actors. But there are some students can who find difficulties in understanding English subtitle. Therefore adding English subtitle is a good way.

English subtitle movie is one medium that is widely used by the students at the present time. The students can improve many new words and phrases, especially idioms and colloquial expressions. The earlier the students get many vocabularies, new accents and the better they will achieve successful in learning English especially, speaking skills in the future. That is why? English subtitle should be used in the students early age, for example since they sit in Junior High School. Therefore, in the of study, the research is to know an effect using English subtitle "Zootopia" movie in speaking skills" of $9^{\text {th }}$ grade of SMPN 6 Sidoarjo.

Individual can speak with each other utilized a language verbally despite the fact that their insight extremely limited. But an essential convey from language verbal or oral. Individuals can express their idea or thoughts through speak with the others. It is aim of speaks, to welcome individuals with a specific end goal to express their thoughts or information for say anything to speakers. From this stated, we are as a speaker could be reaction this inquiring. According to (Richards and Roger 1986, 87) "Grown-up ought to summarize the procedures by children which is gain their 
first language". It means children taught the principal language from speech in type of overwhelming fill activity then grownup will examine better in winning as well. Speaking is critical unit in language teaching causes essentially of the goal of teaching English to the student is to utilize them have speaking ability. Speaking is the activity to talk with people.

According to Nunan, (2003: 40) "Speaking skills is the ability to reveal judgment, ideas, or thought verbally; it is make out legitimate verbal expression to convey meaning in order to be mastered by the people we are talking with". A few people take idea from words when they talk about concept, sense, and meaning what they want to do. Speaking agrees with communication because its purpose to connect all information. Therefore, learner must be practice to speak formal and informal in all area as classroom or environment and it must be doing all day. This is in accordance with Graham (2007) who clarifies that most students trust that the critical objective in learning English is the means by which to have the capacity to manage the stream of discussion orally. Some EFL students in Indonesian, for example, that of led by Efrizal (2012) and Akhyak and Indramawan (2013) discovered diverse conditions of ELF students. Those exploration ventures show a few conditions that the EFL students' speaking ability was bad communication. Some of student, in learning process, were unmotivated in learning their speaking in classroom exercises. The students appeared to be hesitant to uncover their idea when they had a comment (Faulin and Soefendi, 2013). Another issue that makes them hard to pass on their thoughts was that they did not feel certain. Some of them may try to talk yet at that point stalled out when they found that it was hard to continue passing on their thoughts in English (Juhana, 2012), that the point they changed to their native language to keep communicating their thoughts.

The suitable methodology should be connected to include the students in the talking action, and additionally having them develop discussion in view of the point given to them. Additionally, it appears to be important to give curiosity material, which is outstanding by the students. They can without much of a stretch connect with that material (Katsara, 2015). The obvious condition with respect to the EFL students in the schools, especially school in SMPN 6 Sidoarjo ninth grade is the students had low speaking ability. They scarcely proposed their thoughts or reasons in their speaking exercises. Consequently, it is profitable to apply an interactive speaking methodology to enhance their speaking.

The students to give story telling or watching movie, particularly stories that begin from Zootopia movie. Moreover, the students likewise chance to understand about Zootopia movie. They can share many ideas from this movie with their friends. Thusly, it is trust that the utilization of Zootopia movie in the Interactive Storytelling Strategy for talking action would be gainful to enhance the students' speaking ability.

\section{RESEARCH METHOD}

The methodology of the research focuses on the effect of English subtitle in the western movie to improve speaking skills in Junior High School and only discussed the differences between class that improves English through subtitle in western movie and another class which does not use it in teaching and learning 
process. This study explains the value before and after students use this media. The researcher limits the study on the $9^{\text {th }}$ grade of SMPN 6 SIDOARJO. In this research, the researcher used quasi experimental. According to Campbell \& Stanley (1963: 40), the quasi-experimental study was the utilization of pretesting or investigation earlier of accomplishment to find group similarity. In the quasi experiment is systematic can simple much of stretch (but regularly unnoticeably) be presented.

\section{Research Design}

The research was all of seeking, observing and experimental activity normally in the present direct object, to get the actualities.

According to Freeman and Michael, (2004: 20-21) "Experiment had two characterizes: first, there were no less than two groups incorporate in the study, a control and experiment group, and second, the subjects were randomly appoint to one of those groups". "Here, the researcher utilized quantitative or statistic value to handling all of the information incorporates; collecting the information, recognizing the information until analyzing the information. That implied, in the handling the information, the researcher utilized numbers, tables, and so on, Arikunto. (1998: 11)".In this research, the researcher used quasi experimental.

The experimental group was coded with A while Control gather was coded with B. The two classes did pre-test (O1 and $\mathrm{O} 2$ ). It managed so as to know students speaking ability before the treatment. From that point, the treatment (X) was connected to the experimental group. Toward the finish of the treatment, post-test (P1 and P2) was controlled to both experimental group and control group to know the students speaking ability. Thus, the aim of this examination was to answer the exploration question as written in the main chapter, precisely to discover the change in utilizing English subtitled in Zootopia movie in speaking ability for ninth grade of SMP NEGERI 6 SIDOARJO.

The researcher used two classrooms to be well-tried. 9F class has become experimental group and $9 \mathrm{G}$ has become control group. Before giving treatment to the experimental group, the researcher gave pretest for both groups to find out how was students' ability in speaking ability.

\section{Population and Sample}

The population of the study was the second semester students in ninth grade. There were 288 students in nine grader students of SMP NEGERI 6 SIDOARJO. They are 9A until 9H.

In this case, the study took probability sampling. Probability sampling was a sampling technique that provides equal opportunities for each element (member) of the population to be elected as a sample member.

The researcher used the sample of cluster sampling. In this research took two classes which have 36 students in 9F class and 36 in 9G class. The reasons that make researcher choose 9F class as an object of the research because this classroom is not good to speak English. Another reason, some of the student need new way in learning English and the teacher need innovation of English teaching material. In addition, the researcher chose 9F because of students speaking ability is equal with 9G class. 


\section{Instrument}

Instrument was one of the most important parts of the research. Instrument of this research was tested its aim is to measure the student speaking skill. According to (Hansman, 2000) "an instrument was a device which changed a physical variable of measurement to a type of recording which is appropriate. The end goal to measure, to had reliable significance, it was general to utilized a standard arrangement of units by which measurement to be matched".

The researcher used a test. Before coming to experimental stage, the researcher held the pre-experimental stage by using test, pre-test, and post-test. Pretest was given to measure students understanding in speaking skills through the students retelling story about "Legend" before treatment. While post-test was given to measure students understanding in speaking skills through English subtitle movie after treatment.

According to Brown (2003: 3), "test was a tool or method used in measuring person's knowledge, performance, or someone's ability in specific domain". In this case, the researcher held the pre-test and post-test to find out the validity. Validity test used to measure the instrument such as how valid and accurate the instrument. In this research validity test that will use is construct validity.

According to Sugiyono (2017: 177) that construct validity is the test that will be tested by the expert (expert judgment). In this case, after the researcher makes and constructs the test instrument, then the test will judged by the expert. The expert was lecturer and English Teacher.

\section{Data Analysis}

In this study, the data was from quantitative data named test score. This analysis used some statistic tests such as; the normality test, and t-test. The explanation as follows:

\section{The Normality Test}

Normality test was done to find out whether the data of both groups of samples normally distributed or not. If the sample was normally distributed then the population also distributes normally, the conclusions based on computerizing apply by SPSS version of 16 . Where the data showed more than 0.05 was normal.

\section{T-Test}

T-test was also called as partial test. It was used to know whether there were any differences before and after treatment. According to Sugiyono (2010):

$$
t_{0}=\frac{\mathrm{M} 1-\mathrm{M} 2}{\mathrm{SEM} 1-\mathrm{M} 2}
$$

M1: Mean of the Difference of Experiment Class

M2: $\quad$ Mean of the Difference of Control Class

$\begin{array}{ll}\text { SEM: } & \begin{array}{l}\text { Standard Error of } \\ \text { Experiment Class }\end{array} \\ \text { SEM2: } & \begin{array}{l}\text { Standard Error of Control } \\ \text { Class }\end{array}\end{array}$

The Procedure of calculation was as follows:

1. Determining Mean of variable X, the formula was:

$$
\mathrm{M}_{1}=\frac{\sum \mathrm{x}}{\mathrm{N}_{1}}
$$

2. Determining Mean of variable $\mathrm{Y}$, the formula was:

$$
\mathrm{M}_{2}=\frac{\sum \mathrm{Y}}{\mathrm{N}_{2}}
$$


3. Determining standard of deviation score of variable $\mathrm{X}$, the formula was:

$$
\mathrm{SD}_{1}=\sqrt{\frac{\sum_{\mathrm{X}} 2}{\mathrm{~N}_{1}}}
$$

4. Determining standard of deviation score of variable $\mathrm{Y}$, the formula was:

$$
\mathrm{SD}_{2}=\sqrt{\frac{\sum_{\mathrm{x}} 2}{\mathrm{~N}_{2}}}
$$

5. Determining standard error of mean of variable $\mathrm{X}$, the formula was:

$$
\mathrm{SE}_{\mathrm{M}_{1}}=\frac{\mathrm{SD}_{1}}{\sqrt{\mathrm{N}_{1}-1}}
$$

6. Determining standard error or mean of variable $\mathrm{Y}$, the formula was:

$$
\mathrm{SE}_{\mathrm{M}_{2}}=\frac{\mathrm{SD}_{2}}{\sqrt{\mathrm{N}_{2}-1}}
$$

7. Determining standard error of difference of mean of variable $X$ and variable $\mathrm{Y}$, with formula:

$$
\mathrm{SE}_{\mathrm{M}_{1-} M_{2}}=\sqrt{S E_{M_{1}}{ }^{2}+S E_{M_{2}}{ }^{2}}
$$

8. Determining $t_{0}$ with formula:

$$
t_{0}=\frac{\mathrm{M} 1-\mathrm{M} 2}{\mathrm{SEM} 1-\mathrm{M} 2}
$$

9. Determining t-table in significance level $5 \%$ with degree of Freedom (df):

$$
\mathrm{df}=\left(N_{1}+N_{2}\right)-2
$$

Variable X : Teaching watching

Zootopia Movie with English Subtitle.

Variable Y : Teaching watching

Zootopia Movie without English

Subtitle.

\section{FINDING AND DISCUSSION Research Finding}

This research has some steps on analyzing the data such as; validity test, normality test, and T-test. The researcher conducted this research on SMPN 6 Sidoarjo in. It needed three activities which were pre-test, treatment, and posttest. Then, after got the data, it was computed by the formula above. Based on the data analysis and hypothesis analysis, it can be concluded that there is an effect of using English subtitle in "Zootopia" movie to improve students in speaking skill. It was discovered from the result of the data showed that the mean of the students' score in post-test (86.97) was higher than the mean of pre-test (75.86) in $9 \mathrm{~F}$ as experiment class. If the result of the data in $9 \mathrm{G}$ as control class showed that the mean of the students' score in post-test (69.77) was higher than the mean of pre-test (65.27).Thus, there is an effect before and after given treatment between $9 \mathrm{~F}$ and $9 \mathrm{G}$. In this case, the score of $9 \mathrm{~F}$ was higher than $9 \mathrm{G}$.

\section{Discussion}

The researcher discovered the result from T-test which is used to analyze the hypothesis. The obtained data $t_{0}$ and $t_{\text {table }}$ with the significance level is $5 \%$ and degree of freedom is $1.99, \mathrm{t}_{0}$ is 19.90 and $t_{\text {table }}$ is 1.99. It proved that the $t_{0}=19.90>$ $t_{\text {table }}=1.99$. It can be concluded that there is an effect of using English subtitle in "Zootopia" movie in speaking skill for $9^{\text {th }}$ grader of SMPN 6 Sidoarjo. Thus, Ha is accepted, Ho is rejected. There is no doubt that English subtitle is very helpful students for teaching English, especially in speaking skill.

\section{CONCLUSION}

The conclusion was taken from the result of data. It was literally seen from the computation of pre-test and post-test score; the pre-test score was 75.86 compared to 86.97. It was also computed by the T-test 
formula, the $t_{0}$ is 19.90 with the degree of freedom 70 while $t_{\text {table }}$ on the level of significance of 0.05 or $5 \%$.

\section{ACKNOWLEDGMENT}

I give my special thanks to all my students in ninth grade of SMPN 6 Sidoarjo who inspired me to use English subtitle of movie in the classroom. It helps evaluate the progress to speak English more fluently. They helped and support the researcher to finish what has been started. And also thank you for Mrs. Ermawati to guide me about using English Subtitle is very interesting for students. For Mrs. Sri thank you for permitting me to take this data.

\section{REFERENCES}

Campbell T, Donald \& Stanley C, Julian.

(1963). Experimental And Quasi-

Experiment Al Designs For

Research. Houghton Mifflin

Company Boston.

Santoso, Dian. (2017). Implementing

Video Recording to Improve The Content Opening Speech. Journal of English Educators Society, 21-32.

Douglas H, Brown. (2003). Language assessment: principles and classroom practices. San Francisco, California.

Hughes, Rebecca. (2002). Teaching and Researching Speaking. London: Pearson Education.

Megawati, Fika. (2017). Ways For Tertiary Level Students In Building English Speaking Performance. Journal of Linguistic and English Teaching, 137-144.

Irwan D, Darwissyah. (2016). English Education: Jurnal Tadris Bahasa Inggris p-ISSN 2086-6003. Vol 9 (1). 13-28.
John Hansman, R. (2000). Characteristic of Instrumentation. Massachusets Institute of technology: CRC Press.

M Wilga, River. (1970). Teaching Foreign Language Skill. Chicago: University of Chicago Press.

Nunan, David. (2003). Practical English Language Teaching. New York: McGraw Hill. 